The cost that Huaneng quotes for capturing the carbon dioxide before purification - around $\$ 20$ per tonne - is four to five times lower than anything anybody else is reporting, says Mohler. Duke Energy has a partnership with Huaneng and has been planning to analyse the cost of installing and running Huaneng's technology at its Gibson Station power plant in Indiana; Mohler says that joining the consortium's broader assessment will bolster the Gibson analysis and help put this technology in context with other options.

However, Howard Herzog, a chemical engineer researching carbon sequestration at the Massachusetts Institute of Technology in Cambridge, says a deeper inspection of the Shidongkou facility might reveal that its secret comes down to things such as cheap labour and fewer regulatory burdens. "The fact that it's cheaper in China doesn't impress me," says Herzog, who recently toured the facility. "Everything is cheaper in China."

Sarah Forbes, a carbon-sequestration expert at the World Resources Institute, an environmental think tank in Washington DC, says that Huaneng's costs for carbon capture are in proportion with general costs in the Chinese coal industry, which tend to be about one-third of those in the United States.

Ming Sung, who promotes US-Chinese business alliances in Beijing on behalf of the Clean Air Task Force in Boston, Massachusetts, acknowledges that costs will be higher in places such as the United States, but says that the question is how much. Assuming that Huaneng has made some industrial progress, he says, its technology will probably still be cheaper than anyone else's at this stage.

That may not be enough to jump-start the technology, Forbes cautions. "Adding carbon capture to a power plant still comes with a significant cost and energy penalty" that will discourage adoption, she says, and the regulatory drivers necessary to encourage or force take-up are still missing.

Nonetheless, EmberClear, an energy company based in Calgary, Canada, has licensed a suite of Huaneng's clean-coal technologies - including the capture technology in place in Shanghai - for deployment in the West. Albert Lin, chief executive of EmberClear, says the cost reductions that Huaneng has achieved at Shidongkou are probably the result of a mixture of practice and Chinese economics. "Half of it is Chinese costs, but there are definitely improvements in how the technology is being used," he says.

To Friedmann, Shidongkou No. 2 has become a critical case study for exploring actual CCS costs, because of its scale and the real operational data that Huaneng is providing. "There are not that many places where we are going to have the kind of data we are looking for," says Friedmann. "They are the forerunners." -

\title{
France mulls embryo research reform
}

\section{Scientists and clinicians push for a clearer, more permissive law on human embryonic stem-cell work.}

\section{BY DECLAN BUTLER}

$\mathrm{F}$ rance's tight restrictions on human embryonic stem-cell (ESC) research might soon be eased. As parliament prepares to debate the issue next month, Nature has learned that researchers' calls for reform are garnering political support.

Officially, research on human ESCs and embryos is banned in France. But under a 2004 amendment to the country's bioethics law, scientists can obtain dispensation for research that could lead to "major therapeutic progress" for serious diseases that resist other approaches. Those whose research fits the bill - about 30 research groups and 40 projects so far - can carry out research on whole embryos, or on cell lines derived from embryos left over from in vitro fertilization (IVF). Creating embryos for research purposes is illegal in the country, a position that enjoys a broad consensus among scientists, politicians and public alike.

Scientists concede that the 2004 compromise has been a great improvement on the previous outright ban. But it still left uncertainty over the regulatory status of ESCs in France. This uncertainty is a deterrent to foreign researchers and investment by companies, says Marc Peschanski, a neuroscientist working for INSERM, the national biomedical research agency, and head of the Institute for Stem Cell Therapy and Exploration of Monogenic Diseases in Evry, outside Paris. Axel Kahn, a renowned INSERM geneticist and president of the University of Paris-Descartes, calls the current law "an intellectual absurdity and a legal quirk".

A broad consensus of researchers and clinicians is now urging the government to overturn the ban, and to explicitly authorize research on ESCs and whole embryos without the need for any special dispensation.

The law is ripe for reform, says Philippe Menasché, a cardiovascular surgeon working for INSERM at the Georges Pompidou European Hospital in Paris, where his team is researching stem cells as a potential therapy for heart disorders. Conservative politicians' opposition to all forms of embryo research was so fierce in 2004 that most researchers were grateful for any progress, he recalls, but

political and ideological resistance has now largely abated.

The government's draft revised bill, released last October, would maintain the existing system. But last week, a source close to the science ministry told Nature that the ministry will back the explicit authorization of ESC research. After five years without any apparent abuses, politicians are more comfortable with the work, he says. The successful oversight of the national Biomedicine Agency, set up in 2004 to regulate human embryology, genetics and IVF, has had a critical role in inspiring confidence, he adds.

The science ministry is holding off from taking a position on the more controversial issue of research on whole embryos, says the ministry source, preferring to wait until it has heard the views of parliament next month.

Some scientists, including Menasché and Peschanski, say they would be satisfied with

Afterfive years without any apparent abuses, politicians are more comfortable with the work.

pushing for a more complete authorization that includes all forms of such research. This view was endorsed by the influential bipartisan Parliamentary Office for Evaluation of Scientific and Technological Options last July, and by the Conseil d'État, one of the three arms of the country's supreme court system, in a May 2009 report requested by Prime Minister François Fillon.

The outcome of next month's debate is "unpredictable", says Menasché. The government may decide to take the low-risk approach of maintaining the status quo, and any bill must also be approved by the highly conservative Senate. A key factor will be the recommendations of a cross-party parliamentary commission set up to examine the draft bill. Having heard testimony from researchers, it is scheduled to release its report later this month. A source says that the commission is currently "very divided". 